\title{
Chapter 4 \\ The Story of Cash and the Route Toward \\ a Cashless Society: The Case of Sweden
}

\section{History of Swedish Money: From the Tenth Century to the Nineteenth Century}

The Swedish ${ }^{1}$ payment system can be said to have started in 995 as the first Swedish coins were minted in Sigtuna as a response to an increased trade between European merchants. This helped and stimulated trade between Swedish and foreign merchants and thereby became important for the economy in the cities that made the cornerstones of these societies. However, the system was not well developed until the beginning of the seventeenth century when the first banks were created as the chancellor of the realm Axel Oxenstierna stressed the need for banks that could create a better connection between savings and lending in Sweden. As most of the times, this also was in the interest of the King of Sweden Karl X Gustav who was fighting wars in Poland and in need of money to finance the war efforts.

The King awarded the first rights to start a Swedish bank which came in the form of Stockholm Banco in 1656, which was owned by Johan Palmstruch and regulated by the monarch. This bank soon launched credit notes to expand their credit system which led to good business opportunities for the bank. Palmstruch had launched attractive credit services to an economy that was in need of funding to engage in both military and industrial operations. Stockholm Banco seemed to have hit a perfect time with its attractive financial services. Business bloomed. But as we have become aware of over time, financial services and credits cannot expand too much without a sound base. And this became painstakingly evident also for Palmstruch.

Stockholm Banco apparently became somewhat carried away with their success and started to print more bills than they could cover by reliable securities. A bubble was created that later exploded. As creditors to the bank became aware of the problem, a bank run led to the closure of the bank in 1664. Stockholm Banco could simply not repay its creditors since it had given credit that was not covered

\footnotetext{
${ }^{1}$ Even though it should be noted that a notion of the state of Sweden did not exist at this time.
} 
by reliable securities. They faced a situation we still see now and then when banks oversupply credit in order to gain market share and profits.

It is interesting to note that the society of that time was radically tougher than the society today. While today's bankmen face jail sentences or simply mockery in media but generally can leave with a generous compensation package, Johan Palmstruch was sentenced to a death penalty for mismanagement of the bank! Tough times, indeed. It should be noted though that he was later reprieved of this sentence. Seen in this historical light, it is of course very good that our policies regarding financial crimes have changed in a humane direction, but we perhaps not be too sorry for bankmen that misbehave.

The crash of Stockholm Banco led to the creation of a new and highly critical institution in our financial system: the formation of a Swedish central bank. In 1668 the Swedish parliament decided to use the remains of Stockholm Banco to form Riksens Ständers Bank under the ownership and control of the state. This later changed its name to Sveriges Riksbank and became the first central bank in the world. ${ }^{2}$ This did not mean that the money and payment system in Sweden became standardized and homogeneous, though. This was not realized until the formation of the 1897 central banking law through which the Sveriges Riksbank was granted a monopoly on issuing banknotes in Sweden, which came into effect in 1904. Up until 1904 it was perfectly possible for a Swedish bank to issue their own banknotes.

The modern Swedish payment system with a central bank issuing the only form of money that is allowed and also backing its value was thus realized in the early twentieth century. Swedish money has then been meeting many different challenges and using many different solutions as being pegged to gold, to the British pound, to the US dollar, and to baskets of currencies in the Bretton Woods system. The Swedish crown (SEK) eventually became fully convertible and floating in 1992 as the government and the Riksbank found it impossible to defend a fixed exchange rate to other currencies. Not even a 500\% interest rate from the Riksbank helped not maintain a strong Swedish crown ${ }^{3}$ ! The Swedish crown has been freely floating ever since.

\footnotetext{
${ }^{2}$ It should be noted that the Bank of England and the Riksbank are competing regarding which one was the first central bank. The first version of the the Riksbank was founded in 1668 (http://www. riksbank.se/en/The-Riksbank/History/Important-date/1590-1668/) while the Bank of England was founded in 1694 (http://www.bankofengland.co.uk/about/Pages/default.aspx).

${ }^{3}$ https://www.riksbank.se/en-gb/about-the-riksbank/history/1900-1999/interest-rate-500\%2D\%

2Dthe-krona-floats/
} 


\section{The Development of the Swedish Payment System During the Last Secades}

This story can of course start just about anywhere and I have decided to start in the middle of the twentieth century. This is a time when the Swedish economy has initiated its growth and success after WW2 and is about to becoming one of the richest economies in the world. Industry is booming, employment is high, wages and salaries are rising, exports are soaring, and women are entering the labor markets. The social democratic party is ruling the country and a strong welfare state has been launched and is gaining ground. All in all, it is probably one of the best periods in Sweden ever. And, there are several important technologies that are changing the Swedish society like television, automobiles, telephones, household appliances, and many others. But one technology is especially important when we talk about payments - computers are used in more and more applications all over the society. And more specifically, banks are among the most advanced sectors when it comes to automatizing and computerizing their operations.

In the 1960s, banks have already taking steps to make their operations more efficient by launching systems that can run automated processes to control and administer tasks in the banking system. The banks had seen the potential of these systems and invested in building automated systems to operate accounts and transactions, but they lack one critical component: customers. At this time, wages and salaries are often paid directly from the employer to the employee in cash which means that banks do not have access to these funds and potential customers. The banks see a potential to set up a structure that can benefit employers and employees while at the same time attracting new customers to the banks. The transaction bank account is marketed and the large-scale electronic banking system takes an important step forward.

Companies now start to pay wages and salaries directly to employees' bank accounts (electronically) instead of via cash. The employers save costs, the banks get new customers, unions agree as long as banks do not charge consumers for cash withdrawals, and employees like it. It was a win-win-win case that completely changed banking and laid the foundation-the transaction bank account-that still is the core of the payment system.

The ensuing decades reinforced this new system even if the use of cash grew in real terms. The value of cash in circulation in 1950 was around $10 \%$ of GDP and decreased steadily in the coming decades, but that was mainly because the growth of GDP was higher than the growth of cash in circulation. The value of cash in circulation increased from less than 10 billion SEK in the beginning of 1960 to around 55 billion SEK in 1990. Cash is still popular in the 1990s even if electronic payments are becoming more and more popular (Figs. 4.1 and 4.2).

Two important things then happen in the late 1980s and 1990s. Card companies and banks intensify their efforts to transform cash payments into electronic card payments by offering card payments and by introducing fees to payments based on checks. The banks saw benefits from running more efficient electronic systems 


\section{Nominal value of cash in circulation in Sweden (Billion SEK)}

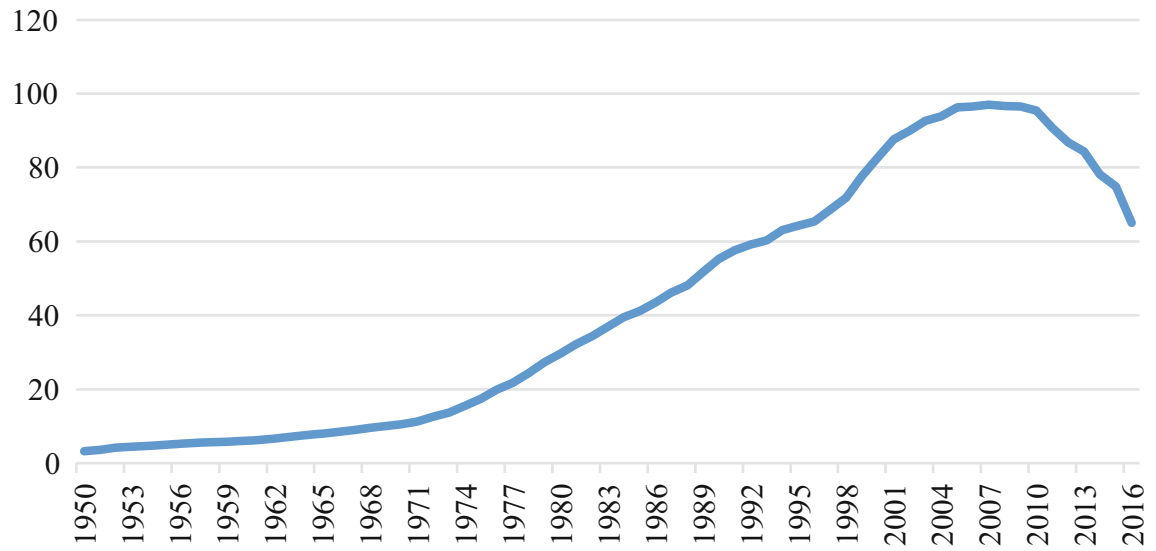

Fig. 4.1 Cash in circulation in Sweden 1950-2016. Source: The Riksbank (https://www.riksbank. se/sv/press-och-publicerat/publikationer/om-finansiell-stabilitet/den-svenska-finansmarknaden/? t_id=1B2M2Y8AsgTpgAmY7PhCfg\%3d\%3d\&_t_q=svenska+finansiella+marknaden\&_t_ tags $=$ language \%3asv\%2csiteid\%3af3366ed3-598f-4166-aa5a-45d5751e940b\&_t_ip=130.237. 51.192\&_t_hit.id=Riksbanken_Core_Models_Pages_ArticlePage/_9dda93fb-bb0c-4416-b2590de7471c3c43_sv\&_t_hit.pos=2)

instead of paper-based systems such as checks and cash, and merchants as well as consumers - at least some segments - also saw advantages compared to the traditional payment services. The use of cards was low in the early stages but grew at a higher speed in the latter parts of the $1990 \mathrm{~s}^{4}$ and soon became a dominant part of retail payments. The number of terminals accepting card payments increased from around 25,000 in 1993 to almost 70,000 in $1996 .^{5}$ The central bank had also invested in and built an electronic system for clearing and settlement of payments - RIX - which provided additional incentives for banks to run electronic payment services. It should be noted however that many became disappointed with the relative slow growth of card payments in Sweden. The development was not as quick as in the neighboring Scandinavian countries. ${ }^{6}$

Interestingly the Swedish banks also tested an electronic form of cash in 1996. It was a cash card function that could be added to a traditional debit card based on the proton system that had been tried and used in Belgium. Money was stored on a chip—which then became a prepaid card — that could be used off-line and without

\footnotetext{
${ }^{4}$ Nyberg, L. and G. Guiborg. 2003. Kortbetalningar i Sverige. Penning- och valutapolitik 2/2003

${ }^{5}$ Sveriges Riksbank, 1997. Sveriges Riksbank. http://www.riksbank.se/sv/Press-och-publicerat/ Publicerat-fran-Riksbanken/Finansiell-stabilitet/Den-svenska-finansmarknaden/?all=1

${ }^{6}$ http://www.riksbank.se/en/Press-and-published/Press-Releases/2003/Nyberg-Overraskande-litenanvandning-av-kontokort-i-Sverige-jamfort-med-vara-grannlander/
} 


\section{Share of GDP $(\%)$}

12.0

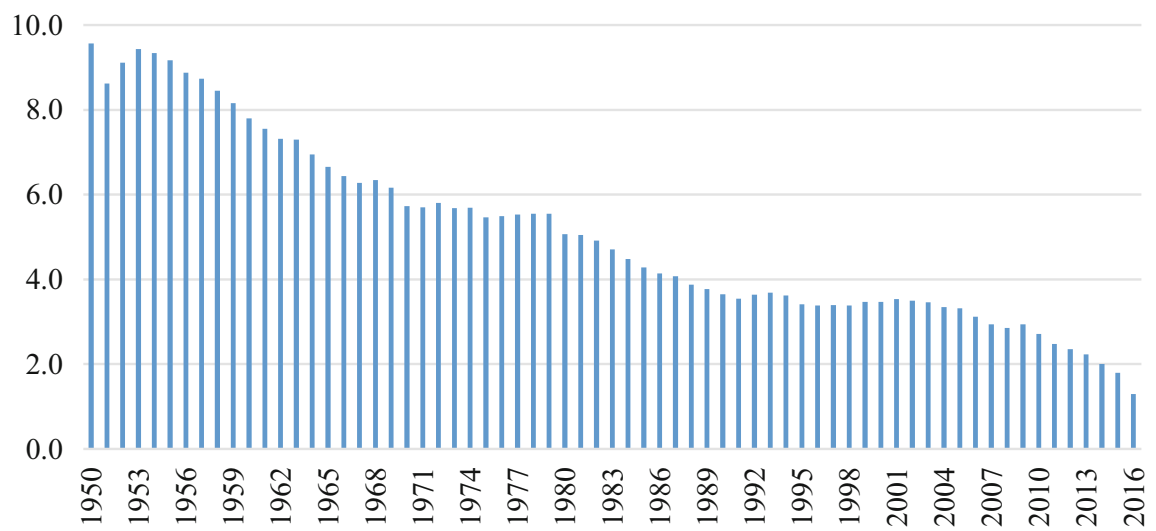

Fig. 4.2 Value of cash in circulation (SEK) as share of Swedish GDP (\%) 1950-2016. Source: The Riksbank (https://www.riksbank.se/sv/press-och-publicerat/publikationer/om-finansiell-stabilitet/ den-svenska-finansmarknaden/?_t_id=1B2M2Y8AsgTpgAmY7PhCfg\%3d\%3d\&_t_q=svenska +finansiella+marknaden\&_t_tags=language \%3asv\%2csiteid\%3af3366ed3-598f-4166-aa5a45d5751e940b\&_t_ip=130.237.51.192\&_t_hit.id=Riksbanken_Core_Models_Pages_ ArticlePage/_9dda93fb-bb0c-4416-b259-0de7471c3c43_sv\&_t_hit.pos=2)

the need for identification and authentification. The benefits were less costly and faster transactions but the service was never really accepted and used by merchants, which meant it was soon closed down. ${ }^{7}$

As the new millennium - the year 2000 - came closer, many in Sweden were enthusiastically engaged in creating a new society. Seductive concepts such as digitalization, a network economy, the new economy, e-commerce, broadband, and many others led to hopes of radical new technologies, business models, and companies that were to change Sweden and turn it into a completely new economy. Another concept that was talked about but really did not happen was mobile payments. The idea that we would be able to make payments through a mobile telephone was appealing and innovative.

The early 2000s saw a time where the hopes for new innovative payment services were high, but few services were launched in a successful way. Banks, telecom operators, and start-ups saw business potential in launching new payment services and intensified their efforts to develop such services but little happened. The time did launch these ideas, however, and became important in the sense that it laid the foundation for ambitions and business ideas that were to become realized 10-15 years later.

\footnotetext{
${ }^{7}$ Den svenska finansmarknaden 1997. Sveriges Riksbank. http://www.riksbank.se/sv/Press-ochpublicerat/Publicerat-fran-Riksbanken/Finansiell-stabilitet/Den-svenska-finansmarknaden/?all=1
} 
The next step was in hindsight somewhat surprising but became an important factor for the reduction of cash in Sweden. In the mid-2000s there was an increase in robberies of banks, merchants, and cash depots which led to new views on cash in the Swedish society. The number of reported robberies ${ }^{8}$ in Sweden increased from 8590 in 2004 to 9398 in 2005-an increase with over 9\% in 1 year. This peak stimulated increased lobbying campaigns against cash by unions in public transportation, banking, and merchants in the mid-2000s. They became active to reduce the use of cash from a work environment perspective since they simply did not want their members - the employees - to be exposed to robberies. Examples of this include Tryggare rörelsen ${ }^{9}$ from the savings banks and Kontantfritt.nu ${ }^{10}$ from the unions in the banking sector. Too many, too brutal, and too costly robberies of buses, banks, and merchants motivated unions to take action aiming at reducing the use of cash in the Swedish society. ${ }^{11}$

Yet another factor relates to the tax system. From $2004^{12}$ and onward, the state introduced several different tax incentives aiming at, first, stimulating the economy via incentives for consumers and, second, turning sectors like construction and household services into transparent and taxpaying industries. Construction and household services to private consumers had a history of being based on nontaxed payments, i.e., part of the gray sector, which meant that suppliers of these services did not pay taxes but where they also often ended up in a poor situation when it came to accessing social benefits like unemployment benefits and pensions. There were additional tax incentives aiming to reduce the use of black money in the construction sector and for household services introduced in 2007. In 2008, the regulation stimulating tax payments for household services also started to include other services like cleaning and gardening. ${ }^{13}$

This meant that private persons could get tax reductions if they paid construction and/or household services for private houses. These incentives stimulated transparency in these sectors which in turn meant the cash payments were replaced by payments primarily via invoicing and therefore affected the use of cash in a negative way.

Another tax and tax evasion factor was the renewed efforts to force merchants to declare all their sales by introducing more strict control of the cash registers used by merchants. One background to these changes aims to make it more difficult for

\footnotetext{
${ }^{8}$ Rån, grovt rån. https://www.bra.se/brott-och-statistik/kriminalstatistik.html

${ }^{9}$ This was a movement aiming to make the society safer by reducing the use of cash. They run information and lobbying campaigns primarily aiming at convincing consumers to make card payments instead of using cash.

${ }^{10}$ This was an information and lobbying campaign from the unions aiming to make people see the benefits from a reduction of the use of cash.

${ }^{11} \mathrm{See}$, for instance, https://www.finansforbundet.se/om-oss/sa-tycker-vi/vara-asikter/kontantfrittsamhalle/

${ }^{12} \mathrm{http} / / /$ www.regeringen.se/rattsdokument/proposition/2004/05/prop.-200304163/

${ }^{13}$ These services were called ROT (Renovering Ombyggnad Tillbyggnad) and RUT (Rengöring Underhåll och Tvätt).
} 
cash-intensive industries to avoid paying taxes. ${ }^{14}$ A new law was introduced in 2007 to realize these ambitions. ${ }^{15}$ The tax authorities wanted to reduce the avoidance of paying taxes in restaurants, temporary merchants, and other merchant activities that traditionally were cash intensive.

The new laws stipulated that all cash registers must be impossible to manipulate and must provide possibilities for tax authorities to get information on sales, which in turn enabled tax authorities to control if they paid correct taxes or not. This made merchants gradually reduce the acceptance of cash and instead start to prefer card payments since these tend to be efficient, not too costly, and often liked by consumers.

In retrospect we see that the use of cash peaked in 2007 in Sweden when the nominal value of cash in circulation was at its highest level. Paradoxically it was at this point in time that the Riksbank made the decision to launch new bills and coins which was implemented in the period 2015-2017. The decision was at the time wellmotivated by efforts to avoid counterfeit money and to make cash handling more efficient.

The Riksbank started to work on how the Swedish bills and coins could be modernized already in $2008 .^{16}$ The main reasons for this were that the bills and coins had not been changed for a long time and there was a need to improve efficiency, to reduce environmental impact, and to improve security. The central bank law was changed in $2009^{17}$ which led to the introduction of new bills and coins in 2015-2017. ${ }^{18}$ There had not been a fundamental change of Swedish cash for 30 years and it was basically time to do this. Somewhat paradoxically these discussions and aims came at the same time as the use of cash in Sweden were at its peak, which happened toward the end of 2007.

Another important event influencing the view of cash in Sweden occurred on September 23, 2009. In the morning of this day, the so-called helicopter robbery of a cash depot in Stockholm took place. This was a rigorously planned and executed robbery of a cash depot where they used a helicopter, explosives, and machine guns to steal 39 million SEK (around 4 million euros). The criminals put fake bombs to stop police helicopters to start and tools to stop police cars ("fotanglar"19), stolen cars, dumped the money, and finally landed the helicopter in a remote area and put it on fire. They got away with the money but one of them was caught.

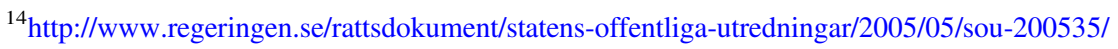

${ }^{15}$ Lagen 2007:592 http://www.riksdagen.se/sv/dokument-lagar/dokument/svensk-forfattningssamling/ lag-2007592-om-kassaregister-mm_sfs-2007-592

${ }^{16} \mathrm{http}: / /$ www.riksbank.se/Upload/Dokument_riksbank/Kat_sedlar/mars_080307.pdf

${ }^{17} \mathrm{http}: / /$ www.riksbank.se/Upload/Dokument_riksbank/Kat_sedlar/2010/Nr16_Riksdagsskrivelse. pdf

${ }^{18} \mathrm{http}: / /$ www.riksbank.se/Documents/Protokollsbilagor/Direktionen/2012/probil_bilagaC_ 120529.pdf

${ }^{19}$ Google translate suggests that "fotangel" is translated into "caltrop" https://translate.google.se/? $\mathrm{hl}=\mathrm{sv} \# \mathrm{sv} / \mathrm{en} / \mathrm{fotangel}$
} 
This spectacular robbery can be seen as the culmination of cash-related robberies in Sweden and led to a debate on whether or not it is a good idea to use cash in our society. I personally wrote an article ${ }^{20}$ arguing that it is time to rethink the use of cash in Sweden and this article led to an emotional debate. A majority of the replies to my article argued strongly and emotionally that cash must be kept and that it was ludicrous to believe anything else. ${ }^{21}$ Some agreed that there is a need to modernize the payment system, but the majority did not. It became very clear that no matter which opinion people had-wanting to keep cash or to get rid of it - the inner beliefs were strong and highly emotional.

This event illustrated the emotional ties to cash as one of the most important symbols of a nation-state and as a highly personal token of what a nation-state is. We confirmed this in a study done in August $2013^{22}$ where we asked 1000 Swedes different questions related to how they make payments. One question was about their view on cash where $2 / 3$ said they see that access to cash is a human right. A human right is comparable to access to food and water, free speech, a transparent and fair legal system, and so on. Interestingly, in the same study, the respondents said they used card payments more frequently than cash payments. It is evident that cash is a strong artefact and institution in our society.

As we know, money and payment services become successful if and when the users trust the system and its services. Cash has therefore a tradition of strong trust since the Swedish Government and the Riksbank - in combination with a lot of other factors-generally have been well equipped to make the Swedish crown a stable and reliable currency. This is especially true for the last 20 years. But it is of course not only the government and the Riksbank that are determining how much users trust the system.

In September 2012, the cash-in-transit service company Panaxia files for bankruptcy after having faced cash flow problems and illegally used clients' money to pay their own costs. ${ }^{23}$ In this process, merchants-grocery stores, petrol stations, and others-lost a lot of money. Some over 100 MSEK. This led to a series of legal trials and the leaders of the company were found guilty and sentenced to imprisonment. The events seemingly led many merchants to question the cash system and to start considering not to accept cash anymore. Another effect from this case was that as Panaxia disappeared from the market, the competitive intensity decreased and fees for cash handling services tended to increase. This of course reduced the incentives for merchants to keep accepting cash.

It is of course a natural effect that cash primarily is used in the so-called proximity payments, i.e., where the payer and the payment receiver meet face-to-face. This

\footnotetext{
${ }^{20}$ Arvidsson, N. Vi behöver ett nytt betalsystem. Svenska Dagbladet, SvD.se, 7 oktober, 2009. https://www.svd.se/vi-behover-ett-nytt-betalsystem

${ }^{21}$ On a personal note, I was called things that cannot be printed in this book by people who had a strong interest to keep cash in Sweden.

${ }^{22} \mathrm{http} / / / \mathrm{www}$. insightintelligence.se/sverige-betalar/det-kontantlosa-samhallet/

${ }^{23} \mathrm{http}: / /$ sverigesradio.se/sida/avsnitt/538117? programid=2519
} 


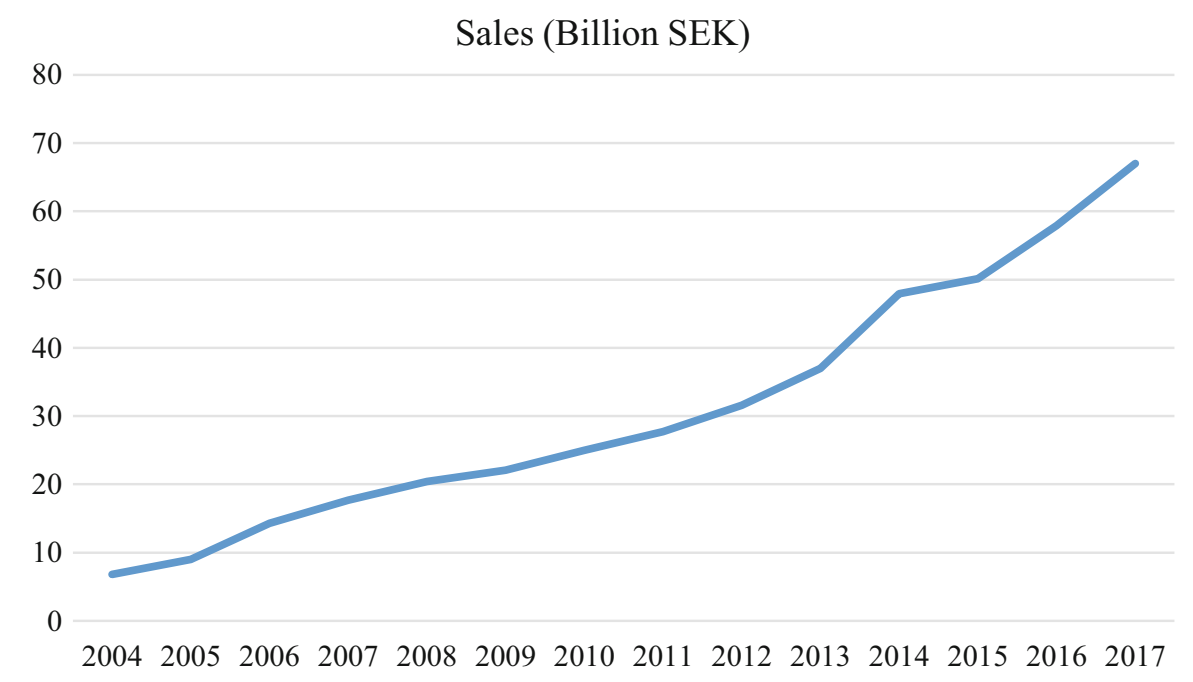

Fig. 4.3 E-commerce in Sweden 2004-2017. Source: E-barometern (2017) (https://www.iis.se/ docs/e-barometern-arsrapport-2017.pdf)

means that as e-commerce grows and starts to replace purchases in physical stores, we should expect a decrease in the use of cash and a proportionate increase in the use of electronic payment services. E-commerce in Sweden has grown each year since 2004 and is currently almost $9 \%$ of all retail trade in Sweden (e-barometern, 2017) but continues to grow steadily in 2018 (e-barometern, 2018 ${ }^{24}$ ). It is still not a major share of all retail trade, but the growth of e-commerce has definitely had an impact on the reduction of cash in the Swedish society.

Payments have increasingly become electronic and new actors are strong in the area of mobile payments and Internet payments-like Apple, Google, Paypal, Klarna, Seamless, iZettle, etc.- - are also attracting young people being active on the Internet to start new purchasing behaviors. This has also stimulated a shift away from physical stores and cash to e-commerce and electronic payments (Fig. 4.3).

But we of course still need to make payments, and if the use of cash decreases, what do Swedes use instead? Well one answer came on December 12, 2012, at 00.12 am when a new mobile payment service called Swish is launched. This is an electronic payment service that initially enabled real-time transactions between consumers (person-to-person payments) without fees and therefore became a natural and efficient substitute to cash. The absence of fees and the real-time clearing makes it similar to cash in the sense that a transaction can be completed in 1 or 2 seconds. By connecting a mobile phone number to a bank account and connecting to a real-time clearing and settlement system, consumers were able to transfer money between bank accounts in a second or two. This meant that situations where people

\footnotetext{
${ }^{24}$ https://www.postnord.se/e-barometern
} 
traditionally had used cash—splitting a bill in a restaurant, transferring money for purchases of gifts or tickets, buying a hot dog and a coffee at the sports arena, or even paying pocket money to kids-now could be handled via a mobile payment service.

After a slow start in 2013, this service gained users and today it has more than 6.5 million private users in a country were around 8.2 million are above the age of 15 . This means that almost $80 \%$ of the potential users already are using it. And they are using it! During the fall of 2017, there were transactions with a value of around 8 billion SEK $^{25}$ per month which is about $10 \%$ of the value of card transactions each month. ${ }^{26}$ In September 2018, there is a transaction of 17.8 billion SEK. ${ }^{27}$ Swish has definitely made an impact when it comes to person-to-person payments in Sweden.

Another factor influencing the view of cash is the economic reports made by the Riksbank as well as the European Central Bank. The socioeconomic reports show that costs of cash are higher than costs of card payments. The social costs of a debit card payment were estimated to be $5.5 \mathrm{SEK}$, while the social costs of a cash payment were estimated to be 8.3 SEK (Segendorf \& Jansson, 2012). The socioeconomic cost of cash payments were shown to be higher than those of debit card payments, which implies that a society may gain from reducing the use of cash. From a macroeconomic perspective, there are strong indications that a society would gain from replacing cash payments with debit card payments.

But there are of course also factors that lead to the conclusion to keep cash. As the reduction of cash continues from 2007 and onward, there are groups in the Swedish society that meet problems. Even if the majority of Swedes seems to adapt to the transition and actually also prefer electronic payment services, there are groups that prefer cash and have difficulties to accessing and depositing cash. The County Administration Board in Sweden ${ }^{28}$ has been given the operative responsibility to study Swedes' access to basic payment services, i.e., access to cash, and their annual reports reveal problems for several groups in the Swedish society.

The latest report on access to basic payment services from the County Administration Board covering 2017 (Länsstyrelserna, 2017) ${ }^{29}$ shows that problems related to poor access to basic payment services are a reality for many people. The report even see a risk of a digital divide where some groups in the society-for different reasons - cannot or will not be able to switch from using cash to using electronic payment services in a quick way and that therefore may risk facing serious difficulties in making payments. These problems are not only related to rural areas far away from the larger cities but can actually be seen in some area in all of the 24 counties in Sweden. It is primarily elderly people with physical and/or cognitive disabilities,

\footnotetext{
${ }^{25}$ https://www.getswish.se/

${ }^{26}$ The total value of POS terminal card transactions in 2016 was 997 billion SEK which gives a monthly average of around 83 billion SEK (http://www.riksbank.se/sv/Statistik/Betalningsstatistik/).

${ }^{27}$ https://www.getswish.se/

${ }^{28}$ Länsstyrelserna www.lst.se

${ }^{29} \mathrm{http}: / /$ www.lansstyrelsen.se/Dalarna/SiteCollectionDocuments/Sv/Publikationer/Rapporter2017/Grundlaggande-betaltjanster-2017.pdf
} 
immigrants, as well as small merchants and organizations in rural areas that have problems when access to cash services deteriorates.

The problems with poor access to basic payment services have also led to a campaign aiming to keep cash or to slow down the decrease of cash in Sweden. There are constellations like "Kontantupproret" 30 (the Access to Cash Campaign) and several interest organizations for retired people like PRO and $\mathrm{SPF}^{31}$ that perform lobbying with the aim to keep cash services in Sweden. "Kontantupproret" is led by Björn Eriksson and can be understood as an interest organization for the industry providing services related to protection and handling cash, ${ }^{32}$ while PRO and SPF are consumer organizations focusing on elderly people. They have a shared interest in keeping cash handling services in Sweden.

In this movement, the former chief-of-police Björn Eriksson published a document called "Korten på Bordet ${ }^{33 "}$ " (Eriksson, 2014 ${ }^{34}$ ) in which he argues that cash payments must be protected and kept as a well-functioning payment service in Sweden. "Kontantupproret" has also acted to convince the government to take the issue of access to cash more seriously as many people are hurt when access to such services is reduced. ${ }^{35}$ PRO has also acted in this matter by collecting names of people that want to keep cash in Sweden. ${ }^{36}$ The lobbying have had an effect as one of the parties in the parliament - the Center Party-announced they will start working to keep cash in Sweden where, for instance, the role of the Riksbank in relation to cash can be changed, ${ }^{37}$ which is discussed later in this book.

Yet another factor in this story is the introduction of new bills and coins in Sweden. As discussed above, this decision was taken in 2008 and implemented in 2015-2017. The change-over process started in October 2015 with new bills in the denomination of 20, 50, 200, and 1000 SEK. Interestingly, Sweden continued the use of the largest bill — the 1000 SEK bill—despite many arguing that it would be a good idea to stop issuing larger bills. It should be noted that 1000 SEK is

\footnotetext{
${ }^{30}$ The literal translation of "kontantupproret" is "cash rebellion" (http://www.kontantupproret.se/).

${ }^{31}$ Like Pensionärernas Riksorganisation (www.pro.se) and SPF (www.spfseniorerna.se)

${ }^{32}$ This includes companies like Loomis www.loomis.se and Nokas www.nokas.se.

${ }^{33}$ This translates into "Cards on the table."

${ }^{34}$ Interestingly, Björn Eriksson accuses the banks of driving an intensified lobbying campaign for getting rid of cash, while he in fact is doing the exact same thing - supported by companies providing services connected to cash handling - but with the aim to keep cash in the Swedish society.

${ }^{35}$ They have written (in Swedish): Vår uppfattning är att Riksbanken och Kontantupproret tycks ha en samsyn i många frågor. Vi tycks dela verklighetsbeskrivningen om hur människor blir lidande av bankernas forcerade nedmontering av kontantsystemet. Vi uppfattar det också som att Riksbanken delar vår syn att det är problematiskt att bankväsendet har fått obegränsat inflytande över kontanthanteringen och att de berörda bankerna kan fortsätta att pressa fram sina positioner utan motstånd. See http://www.kontantupproret.se/wp-content/uploads/2014/11/Skrivelse-tillRiksbanksfullma\%CC\%88ktige-fra\%CC\%8An-Kontantupproret-dec-2015.pdf

${ }^{36} \mathrm{http}: / / \mathrm{www}$.pro.se/pension/Nyhetsarkiv/Kontanter-behovs/

${ }^{37} \mathrm{https}: / /$ www.centerpartiet.se/lokal/fyrbodal/uddevalla/startsida/nyheter/nyheter/2017-01-28centerpartiet-riksbanken-maste-se-till-att-kontanter-finns.html
} 
approximately 100 euro or 120 USD which means it still has a rather low value if we compare to the largest bills in euro or USD. The old bills with denominations 20, 50, and 1000 SEK became invalid in June 2016. New bills denominated 100 and 500 SEK as well as coins denominated 1, 2, and 5 SEK came in October 2016. Finally, old bills denominated 100 and 500 SEK as well as coins denominated 1,2, and 5 SEK became invalid in June 2017.

The introduction of new bills and coins does not seem to have had a positive effect on the use of cash, though. If anything, it seems to have had the opposite effect. One temporary effect is of course that all the old cash never returned to the central bank at all and therefore disappeared from the official statistics, but another seems to be that consumers and merchants seemingly have transformed their behavior and now instead are using electronic payment services instead of cash.

The value of all cash in circulation after the introduction of new bills and coins was around 50 billion SEK in October $2017^{38}$ which is about $65 \%$ of the value in 2015 before the process started. The reduction only in 2017 is around 23\%, and in the end of September 2018, the value of cash in circulation was 7\% lower than the monthly average in $2017^{39}$ ! Paradoxically, it is not unlikely that instead of stimulating a renewed interest in cash, the new bills and coins led to a decreased interest in cash.

The decision to launch the new cash definitely made sense when it was taken as this was when the use of cash peaked. None at that time had foreseen the decline in the use of cash that has happened. As always, it is much easier to look backward and argue they were wrong than to look forward and rightly say how things should be done. A logical decision in 2008 given the information and knowledge at hand but that in retrospect may seem incorrect. And if you add that cash will still be around for a long time even if the use of it decreases, the decision to launch new bills and coins was justified.

There are several historic factors that can explain the reduction of cash in Sweden, but I will now turn to more recent factors.

\section{References}

E-barometern. (2017). Årsrapport i samarbete mellan Svensk Digital Handel och HUI Research. E-barometern. (2018). Årsrapport i samarbete mellan Svensk Digital Handel och HUI Research. Eriksson, B. (2014). Korten på bordet-därför vill bankerna avskaffa kontanterna.

Länsstyrelserna. (2017). Bevakning av grundläggande betalningstjänster 2017. Falun: Länsstyrelsen i Dalarna.

Nyberg, L., \& Guiborg, G.. (2003). Kortbetalningar i Sverige (Penning-och valutapolitik 2/2003).

\footnotetext{
${ }^{38} \mathrm{http}: / / \mathrm{www}$. riksbank.se/sv/Sedlar\%2D\%2Dmynt/Statistik/

${ }^{39} \mathrm{https} / / / \mathrm{www}$. riksbank.se/sv/statistik/betalningar-sedlar-och-mynt/sedlar-och-mynt/
} 
Segendorf, B., \& Jansson, T. (2012). The cost of consumer payments in Sweden (Sveriges Riksbank Working Paper Series, no. 262).

Sveriges Riksbank. (1997). Den svenska finansmarknaden. Stockholm: Sveriges Riksbank.

Open Access This chapter is licensed under the terms of the Creative Commons Attribution 4.0 International License (http://creativecommons.org/licenses/by/4.0/), which permits use, sharing, adaptation, distribution and reproduction in any medium or format, as long as you give appropriate credit to the original author(s) and the source, provide a link to the Creative Commons licence and indicate if changes were made.

The images or other third party material in this chapter are included in the chapter's Creative Commons licence, unless indicated otherwise in a credit line to the material. If material is not included in the chapter's Creative Commons licence and your intended use is not permitted by statutory regulation or exceeds the permitted use, you will need to obtain permission directly from the copyright holder. 